\title{
Genetics and congenital heart disease ${ }^{1}$
}

\author{
Richard Emanuel \\ From The National Heart Hospital, the Institute of Cardiology, and the Cardiac Department, \\ Middlesex Hospital, London W.I
}

In isolated congenital heart disease genetic factors have been shown from family studies, individual pedigree analyses, the frequency of consanguinity, examination of data from twins, and possibly from cytogenetics. In defects of the atrial septum, where data are most complete, genetic factors appear to be important, particularly in secundum atrial septal defect.

In the syndromes with abnormal chromosomes in which congenital heart disease is common, the cardiovascular abnormality is probably directly associated with the abnormal genetic material present.

In hereditary disorders with normal chromosomes in which congenital heart disease features, the pattern of inheritance suggests transmission by a single gene or group of genes. The cardiovascular abnormality is genetically determined, though it may not become apparent until many years after birth.

Cardiology and genetics have developed independently and both have become important branches of medical science during the past 25 years. Until recently, there has been little interchange of ideas between these two disciplines, and few interested in cardiology, with the exception of Maurice Campbell in this country and Victor McKusick in the United States, have ventured into the field of genetics. It was this that prompted the choice of the title Genetics and Congenital Heart Disease for the St. Cyres Lecture of 1968.

An interplay of genetic and environmental factors accounts for most diseases, including congenital heart disease. The contribution of these factors may at times be easily determined, as in pneumoconiosis, where environment is important, or in haemophilia, which is genetically determined. In most types of congenital heart disease, genetic influences cannot be quantitated, but examination of the experimental and clinical data has contributed to an understanding of their importance in man.

The study of human genetics is difficult, as man is not prolific in comparison with many animals, and it takes him 15-20 years to complete a generation. An initial survey has therefore been made of experimental and domestic animals where reproduction is relatively rapid and selective breeding is possible.

1 The St. Cyres lecture delivered at the Royal College of Physicians, London, 5 December 1968.

\section{Genetics and congenital heart disease. in animals}

In animals, information on congenital heart disease is scarce, but two facts suggest that genetic factors may be important. The first is that congenital heart disease is commoner in pure-bred strains than in animals derived from mixed breeding. The second is that in certain breeds and species particular types predominate (Detweiler, 1964; Patterson, 1965). For instance, in the dog, Patterson (1965, 1968) has shown that pulmonary valve stenosis is most commonly seen in the chihuahua, bulldog, fox-terrier, and beagle; subvalve aortic stenosis is found in the Alsatian and boxer, and persistent ductus arteriosus appears in the poodle, collie, and Pomeranian, but the possible influence of environmental factors in the latter has not yet been excluded (Patterson and Detweiler, 1967). In the pig there appears to be an unusual frequency of subvalve aortic stenosis and atrioventricular defect (Emsbö, I955; $\mathrm{Nie}$ 1963).

There are few experiments on selective breeding in animals with congenital heart disease. In Siller's (1958) necropsy study of 613 Brown Leghorns, he examined fowls from 6 inbred strains and showed a high incidence of ventricular septal defect in 3 (84.2, 49.5 , and $31.4 \%$ ) and a significantly lower incidence in the remaining $3(5.9,5.0$, and 3.6\%). Fox (1967) obtained similar results in the rat (Long-Evans); keeping 2 inbred 
substrains under identical laboratory conditions, she found $25 \%$ of the Olson-Goss strain had a membranous ventricular septal defect, while only $4 \%$ of the Californian strain were affected.

The available experimental data from animals do little more than suggest that genetic factors may have an influence on the development of congenital heart disease in some species. There is no information on primates, and nothing to suggest that the evidence from lower animals is directly applicable to man.

\section{Genetics and congenital heart disease in man}

Clinical material can be divided into 3 groups for the study of genetic factors in man: group I, isolated congenital heart disease; group II, syndromes with abnormal chromosomes, not necessarily hereditary, in which congenital heart disease is common but is only one of the many abnormalities present; group III, hereditary disorders with normal chromosomes in which congenital heart disease is common but is only one of the abnormalities present.

Information on the importance of genetic influences can be derived from the study of familial incidence, individual pedigree analysis, the frequency of consanguinity, twin involvement, and cytogenetics. Not all these forms of analysis are applicable to each clinical group, and in many instances, though the mode of analysis is applicable, data have not yet been collected.

\section{Group I: Isolated congenital heart disease}

(a) Familial incidence The frequency of congenital heart disease in Western Europe and the United States is now accepted as between 5 and 7 per 1,000 live births (Carlgren, 1959; McKeown and Record, 1960; Mustacchi, Sherins, and Miller, 1963; Smithells, 1968) and 8.3 per I,000 if stillbirths are included (Richards et al., 1955). It is not uncommon for several members of a family to be affected, and those that are, frequently have the same, or closely related, anatomical defects (McKeown, MacMahon, and Parsons, 1953; Howitt, 196I; Burman, 196I ; Pitt, 1962; Christensen and Nelson, 1963). Many affected families have been reported, and when Gänsslen, Lambrecht, and Werner reviewed the subject in 1940 they were able to cite 68 examples. A typical family, personally studied, is shown in Fig. I in which 3 of the 5 sibs had Fallot's tetralogy. Over the years these findings have given rise to specula-

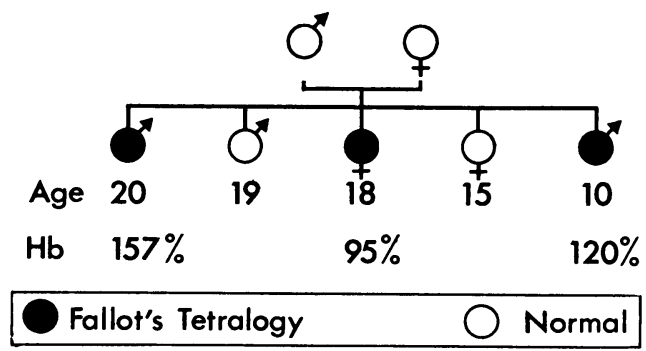

FI I Fallot's tetralogy occurring in 3 of 5 sibs. The haemoglobulin levels indicate the clinical severity.

tion on the inheritance of isolated congenital heart disease, and all simple modes of transmission, except sex-linked inheritance, have been postulated.

Systematic family studies over the past 15 years have shown that there is no single or simple mode of inheritance in the majority of types of isolated congenital heart disease. Campbell and Polani's studies showed that, in Fallot's tetralogy, persistent ductus arteriosus, secundum atrial septal defect, pulmonary venous stenosis, and ventricular septal defect, if one child was affected the other sibs were at increased risk, but that generally there was no increased frequency of congenital heart disease in either the parents or the children of the index cases. In contrast they found that in secundum atrial septal defect the parents as well as the sibs had an increased frequency of congenital heart disease, and in coarctation of the aorta not even the sibs of the index cases were at increased risk (Polani and Campbell, 1955, 1960; Campbell and Polani, 196ra, b; Campbell, 1962; Campbell and Goodwin, 1965). This information was collected by questionary, without examination of relatives, and it is therefore likely that the frequency of congenital heart disease reported is too low.

Recent family studies designed to examine all first degree relatives have shown somewhat different results. In aortic stenosis, secundum atrial septal defect, atrioventricular defect, and transposition, the sibs were at increased risk as in the earlier studies, but in secundum atrial septal defect and atrioventricular defect, the parents, and in atrioventricular defect and persistent ductus, the children, were also at increased risk (Zoethout, Bonham Carter, and Carter, 1964; Nora et al., 1967b; Emanuel et al., 1968; Fuhrmann, I968b; Wilkins, 1969).

The detailed family studies now available 
in secundum atrial septal defect (Nora et al., 1967b) and atrioventricular defect (Emanuel et al., 1968) make it possible to compare the relative importance of genetic factors in these two lesions. In secundum atrial septal defect, more first degree relatives were affected, the familial incidence was higher, and more of the affected first degree relatives had a lesion identical to the index case than in atrioventricular defect (Table $\mathrm{r}$ ). Using Falconer's (1965) method of analysis these data can be expressed in terms of heritability, which also show that genetic factors are more important in secundum atrial septal defect, where the heritability is $70 \%$ compared with $45 \%$ in atrioventricular defect (Table I).

Information from these family studies has provided data that are useful for genetic counselling. The risk of congenital heart disease in the general population is between 0.5 and 0.7 per 100 live births. Considering congenital heart disease as a whole, if there is already I affected child in the family the risk to subsequent children increases to $2-4 \%$, and if there are 2 affected sibs the risk is even higher at 5-8\% (Fuhrmann, I968a; Polani, 1968), but in lesions such as secundum atrial septal defect and atrioventricular defect, the risk is likely to be higher still (Emanuel et al., 1968).

(b) Individual pedigree analysis Study of an individual pedigree is rarely helpful in isolated congenital heart disease, as it is uncommon for this type of defect to be transmitted as a simple dominant or recessive, but there appear to be at least 3 exceptions. One is hypertrophic cardiomyopathy with or without obstruction (Teare, I958; Goodwin et al., 1960; Frank and Braunwald, 1968), in about one-third of which the defect is familial and transmitted as an autosomal dominant, as was well shown in the family reported by Hollman and colleagues (1960). Another form of defect inherited as an autosomal dominant is the rare type of supravalve aortic stenosis without evidence of hypercalcaemia. These children are mentally normal with normal facies, and the subject has been reviewed by Merritt et al. (1963) and Logan et al. (1965). Finally, there is the rare family in which a secundum atrial septal defect appears to be transmitted as an autosomal dominant with variable penetrance. The most quoted example is perhaps that of Zuckerman et al. (I962) in which there were 9 cases in 4 generations.

(c) Consanguinity When a malformation is caused by a recessive gene, an individual
TABLE I Relative importance of genetic factors in atrioventricular defect and secundum atrial septal defect (Emanuel et al., 1968; Nora et al., $1967 b$ )

\begin{tabular}{llll}
\hline & $\begin{array}{l}\text { Familial incidence } \\
\text { of congenital } \\
\text { heart disease }\end{array}$ & $\begin{array}{l}\text { Identical cardiac } \\
\text { defects in propositi } \\
\text { and first degree } \\
\text { relatives }\end{array}$ & Heritability \\
\cline { 2 - 4 } & $20 \%$ & I in 8 & $45 \%$ \\
$\begin{array}{l}\text { Defect }\left(92^{\star}\right) \\
\text { Secundum atrial } \\
\text { septal defect }\left(100^{\star}\right)\end{array}$ & $32 \%$ & I5 in 17 & $70 \%$ \\
\hline
\end{tabular}

$\star$ Number of families studied.

t Falconer (1965).

carrying one such gene (heterozygote) will be clinically normal, but an individual with two recessive genes (homozygote) will be affected. If, therefore, an abnormal recessive gene is present in a family, intermarriage may produce individuals carrying two such genes, who will be clinically abnormal. Hence, a malformation associated with a high incidence of consanguinity suggests transmission by a recessive gene. The frequency of firstcousin marriages in congenital heart disease has been studied and the data from three European countries are in general agreement (Campbell, 1965). Campbell's figures are given in Table 2, and to them has been added information on atrioventricular defect (Emanuel et al., 1968) and congenital aortic stenosis (Zoethout et al., 1964). The data suggest that a recessive gene may be a factor in situs inversus, secundum atrial septal defect, persistent ductus, and ventricular septal defect, and possibly also in pulmonary valve stenosis and Fallot's tetralogy. American

TABLE 2 Consanguinity of parents in congenital heart disease (Campbell, 1965) (Normal mean 0.4-0.5)

\begin{tabular}{ll}
\hline & $\begin{array}{l}\text { No. of first cousin } \\
\text { marriages in parents } \\
\text { of propositi }\end{array}$ \\
\hline Situs inversus & $5 \cdot 3$ \\
Atrial septal defect & $\mathrm{I} \cdot 9$ \\
Persistent ductus arteriosus & $\mathrm{I} \cdot 6$ \\
Ventricular septal defect & $\mathrm{I} \cdot \mathbf{2}$ \\
Pulmonary valve stenosis $\ldots \ldots \ldots \ldots \ldots \ldots \ldots$ & 0.9 \\
Fallot's tetralogy & $0 \cdot 8$ \\
Coarctation & 0 \\
Atrioventricular defect & 0 \\
Aortic stenosis & 0
\end{tabular}

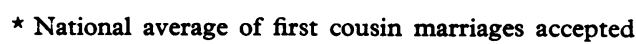
as between 0.4 and $0.5 \%$ (Bell, 1940; Roberts, 1955). 
work has not confirmed these findings, but this could be due to legislation against firstcousin marriages in certain States (Fuhrmann, 1968a).

(d) Twin studies Identical twins (monozygotic) derived from one ovum have a far greater genetic similarity than dissimilar twins (dizygotic) that are derived from two ova. If, therefore, genetic factors are important in a disease, it should occur in both members of identical twins more frequently than in both members of dissimilar twins. It is because of this that geneticists study twins when trying to determine the relative importance of genetic and environmental factors. Pitfalls in this work have been considered by the World Health Organization in 1966 and also by Harvald and Hauge (1965).

Once again, the data on isolated congenital heart disease are scant, and great care has to be taken not only in the mode of selection of the twins but also in the validity of the evidence on which their zygosity is based. Nora et al. (1967a) have reviewed the published work and found ro acceptable studies (Table 3). They showed that congenital heart disease was present in both members of monozygotic twins much more frequently than in both members of dizygotic twins, which is further evidence for the presence of genetic factors.

(e) Cytogenetics In 1963, Sasaki, Makino, and Kajii from Tokyo reported autosomal abnormalities in 9 out of 22 patients with congenital heart disease. Six of these had an atrial septal defect, which was uncomplicated in 4, but associated with additional cardiac defects in 2. The type of atrial septal defect was only specified in 3 cases, where it was a secundum lesion.

This work prompted us at the National Heart Hospital and Institute of Cardiology to make a systematic study of cytogenetics in isolated congenital heart disease. We examined 250 cases which included 32 with secundum atrial septal defect and 22 with atrioventricular defects. No major chromosome abnormality was found, but in 6 patients distinct autosomal variants occurred. In 4 of the cases the variant was in autosome 16, which is the most pleomorphic of all autosomes. In 3 cases the cardiac defect was an atrioventricular defect and in 3 coarctation of the aorta, both lesions occurring together in one case (Table 4) (Anders, Moores, and Emanuel, 1965; Moores, Anders, and Emanuel, 1966). We studied the families of these 6 index cases and showed, in each
TABLE 3 Frequency of congenital heart disease in randomly selected twins

\begin{tabular}{lclll}
\hline & Totals & $\begin{array}{l}\text { Discordant } \\
\text { pairs }\end{array}$ & $\begin{array}{l}\text { Concordant } \\
\text { pairs }\end{array}$ & $\begin{array}{l}\text { Per cent } \\
\text { concordant }\end{array}$ \\
\hline $\begin{array}{l}\text { Monozygotic } \\
\text { Dizygotic }\end{array}$ & 88 & 65 & 23 & 26 \\
\hline
\end{tabular}

Dogramaci and Green (1947); McAleese (1952); Holman, Gerbode, and Purdy (1953); Anderson (1954); Lamy, de Grouchy, and Schweisguth (1957); Uchida and Rowe (1957); Ross (1959); Campbell (1961); Fuhrmann (1962); Nora et al. (1967a)

instance, that the chromosome variants were an inherited characteristic but independent of congenital heart disease, which suggested they played no part in the aetiology of congenital cardiac defects (Fig. 2 and 3 ). This view was supported by the findings of Court Brown, Jacobs, and Brunton (I965), which showed a frequency for similar variants in the general population of $I$ in 44 (IO2O cases studied). This figure was comparable to ours in isolated congenital heart disease of I in 42 (250 cases studied). German, Ehlers, and Engle (1966), however, reported similar autosomal variants in 4 out of 35 cases of familial cardiac defects, a frequency of $I$ in 9. They thought this higher figure could be significant, but further work is needed to elucidate the point.

The importance of genetic factors in most types of isolated congenital heart disease has been shown from family studies and from individual pedigree analysis in certain cardiomyopathies, supravalve aortic stenosis without hypercalcaemia, and in the occasional family with secundum atrial septal defect. The presence of a recessive gene has been suggested by an increased frequency of first-cousin marriages in situs inversus, secundum atrial septal defect, persistent

TABLE 4 Six patients with autosomal variants in 250 cases of congenital heart disease

\begin{tabular}{|c|c|c|}
\hline Patient & $\begin{array}{l}\text { Autosomal } \\
\text { variant }\end{array}$ & Cardiac lesion \\
\hline A. $T$. & Long 16 & $\begin{array}{l}\text { AV defect + pulmonary } \\
\text { valve stenosis }\end{array}$ \\
\hline $\begin{array}{l}\text { J.M. } \\
\text { M.W. } \\
\text { E.B. } \\
\text { S.L. } \\
\text { Y.S. }\end{array}$ & $\begin{array}{l}\text { Short } 16 \\
\text { Short } 16 \\
\text { Long } 9 \\
\text { Unusual I5 } \\
\text { Long I6 }\end{array}$ & $\begin{array}{l}\text { AV defect + coarctation } \\
\text { AV defect } \\
\text { Coarctation } \\
\text { Coarctation } \\
\text { Persistent ductus arteriosus }\end{array}$ \\
\hline
\end{tabular}


ductus arteriosus, and ventricular septal defect. Twin studies provide further evidence for genetic factors. Finally, the significance of autosomal variants in familial congenital heart disease remains to be assessed.

\section{Group II: Syndromes with abnormal chromosomes in which congenital heart disease is common but is only one of many abnormalities present}

Gross physical and mental abnormalities occur in these syndromes, so that many of those affected die young or need life-long institutional care. The associated cardiac defect may be a relatively unimportant part of the whole clinical picture. In this group there are 4 syndromes of interest to the cardiologist. They differ one from another and each has a defined pattern of cardiovascular abnormalities (Table 5).

(a) Down's syndrome (trisomy 21) The frequency of congenital heart disease in this condition differs according to the material studied and the diagnostic criteria used. It varies from $40 \%$ in a prospective clinical study (Rowe and Uchida, I96I; Rowe, 1962) to $56 \%$ in a necropsy series (Berg, Crome, and France, 1960). The frequency of atrioventricular defect and ventricular septal defect is agreed by most authors. Each of these lesions accounts for about one-third of the cases of congenital heart disease in Down's syndrome (Berg et al., 1960; Rowe and Uchida, 196r; Polani, 1968). The frequency of atrioventricular defect in this syndrome is in sharp contrast with its frequency in congenital heart disease as a whole, where it accounts for about $I \%$ of all cardiac defects (Watson, 1968). The association between Down's syndrome and atrioventricular defect remains unexplained.

(b) and (c) Patau's syndrome (trisomy 13) and Edwards's syndrome (trisomy 18) In these rare syndromes, congenital heart disease is usual, but owing to gross developmental abnormalities it is rare for those affected to survive infancy (Weber et al., 1964). Cardiac defects may be multiple, ventricular septal defect, persistent ductus arteriosus, dextrocardia, and secundum atrial septal defect predominating in Patau's syndrome, but in Edwards's syndrome ventricular septal defect, persistent ductus and pulmonary valve stenosis are common, while dextrocardia is exceptional (Warkany, Passarge, and Smith, 1966; Polani, 1968).

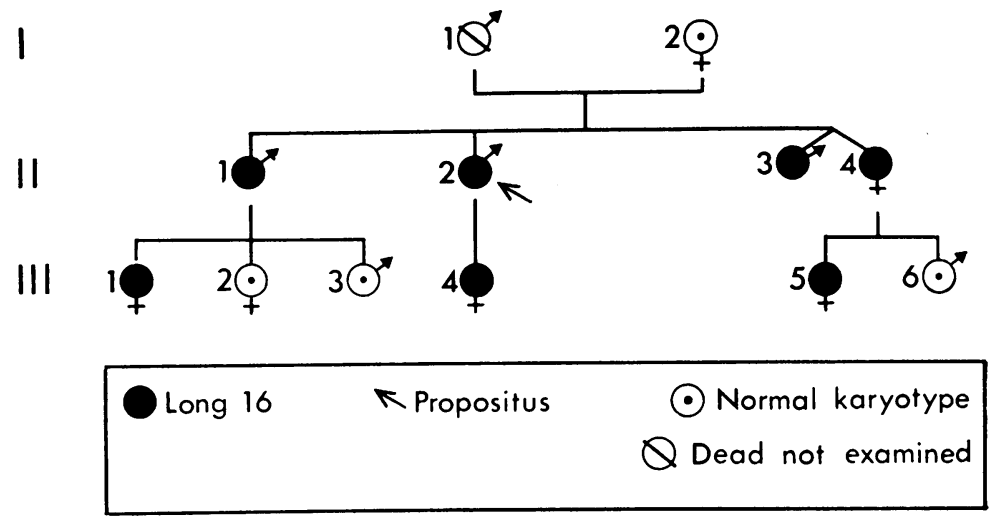

FIG. 2 Pedigree of A.T.: I.I died at 47 years from heart disease of unknown aetiology. III.I and III.2 were not examined clinically. The propositus had an atrioventricular defect and pulmonary valve stenosis, in addition to a long autosome 16. A similar chromosome variant was seen in his 3 sibs and 3 of the 6 members of the next generation, all of whom had normal hearts.

(d) Turner's syndrome (monosomy $\mathbf{X}$ ) In classical Turner's syndrome with monosomy $\mathrm{X}$, congenital heart disease occurs in $20 \%$ of cases. The predominant lesions are congenital aortic valve stenosis and coarctation of the aorta, which may occur singly or together. Pulmonary valve stenosis is rare (Polani, Hunter, and Lennox, 1954; Polani, 1968).

This syndrome is by no means a single entity but includes many clinical and cyto-

\section{FIG. 3 Pedigree of S.L. The propositus and} 3 other members of the family had an abnormal autosome 15 (long short arms). The propositus, who had coarctation of the aorta, was the only member of the family known to have congenital heart disease.
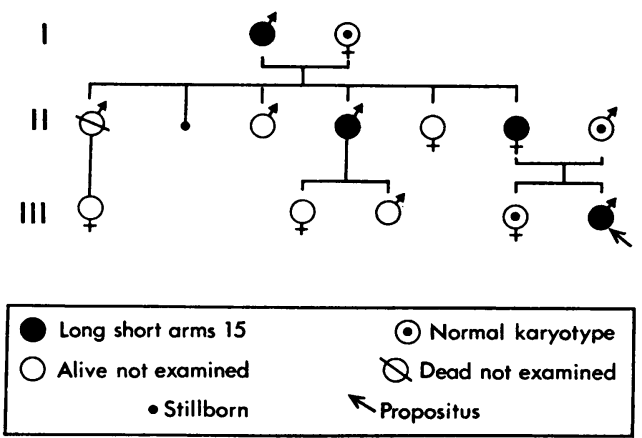
genetic variants (Polani, 1962; Lancet, 1965). One of the better defined is the TurnerUllrich syndrome, a condition clinically indistinguishable from Turner's syndrome but with normal chromosomes. Here, however, pulmonary valve stenosis and congenital abnormalities of the pulmonary arteries are relatively common, accounting for approximately one-third of all the congenital heart disease (Vernant et al., 1966; Migeon and Whitehouse, 1967; Polani, 1968).

Fig. 4 illustrates some of the variants. The girl with Turner's syndrome had monosomy $\mathrm{X}$ and both congenital aortic valve stenosis and coarctation of the aorta, proved at operation. Unusual features were normal stature, normal intelligence, normal development of the breasts, and normal menstruation. The other girl was an example of the TurnerUllrich syndrome. She had all the clinical stigmata of Turner's syndrome including mental retardation, but the chromosomes were normal and she had pulmonary atresia, proved at thoracotomy.

At present we can only speculate on the role of abnormal chromosomes in congenital heart disease, but it seems reasonable to postulate that, when extra genetic material is present, as in the trisomic syndromes, it becomes genetically active at a precisely

FIG. 4 An example of Turner's syndrome and Ullrich's syndrome (see text). The figures for the different types of congenital heart disease seen in each syndrome have been collected from various authors.

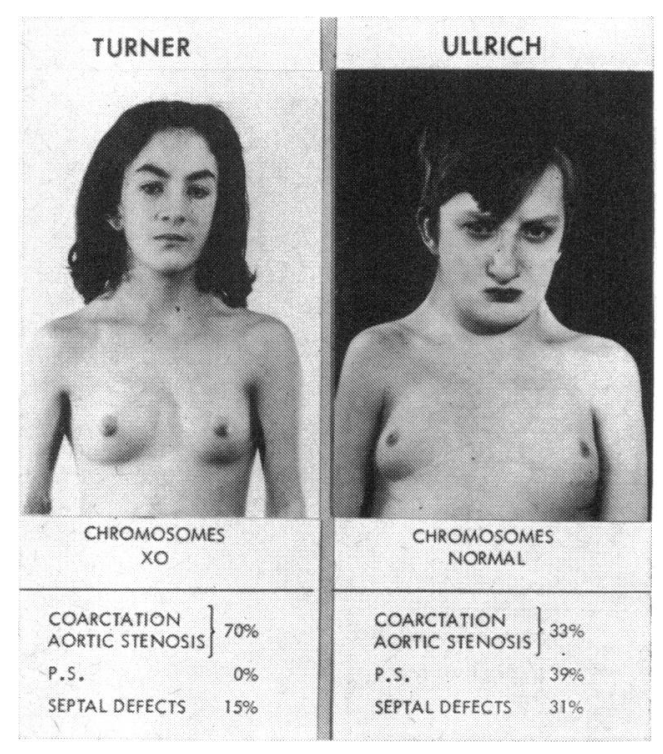

TABLE 5 Syndromes with abnormal chromosomes and congenital heart disease

\begin{tabular}{|c|c|c|}
\hline Syndrome & $\begin{array}{l}\text { Frequency of } \\
\text { congenital } \\
\text { heart disease } \\
(\%)\end{array}$ & Type of congenital heart disease \\
\hline $\begin{array}{l}\text { Down's } \\
\quad \text { (trisomy 2I) }\end{array}$ & $40-56$ & $\begin{array}{l}\text { AV defect; ventricular septal } \\
\text { defect }\end{array}$ \\
\hline $\begin{array}{l}\text { Patau's } \\
\quad \text { (trisomy 13) }\end{array}$ & $80-90$ & $\begin{array}{l}\text { Ventricular septal defect }+ \\
\text { persistent ductus arteriosus }\end{array}$ \\
\hline $\begin{array}{l}\text { Edwards's } \\
\text { (trisomy I8) } \\
\text { Turner's }\end{array}$ & Over 97 & $" \quad " \quad$ " \\
\hline (monosomy $\mathbf{X}$ ) & 20 & Coarctation; aortic stenosis \\
\hline
\end{tabular}

defined time during foetal development. In the case of Down's syndrome this appears to be when the atrial septum and upper part of the ventricular septum are developing, hence the predominance of atrioventricular and ventricular septal defects.

Similarly, in the classical Turner's syndrome with monosomy $\mathrm{X}$, the common cardiological defects are congenital aortic stenosis and coarctation of the aorta. It is tempting to associate the frequency of these male lesions in the phenotypically female Turner with the absent $\mathbf{X}$ chromosome.

Group III: Hereditary disorders with normal chromosomes in which congenital heart disease is common but is only one of the many abnormalities present

There are now more than 30 syndromes with cardiovascular abnormalities included in this group (McKusick, I964). All are rare, and they include Marfan's syndrome, haemochromatosis, Friedreich's ataxia, dystrophia myotonica, glycogen storage disease, and the Ellis-van Creveld syndrome. Study of individual pedigrees shows a dominant or recessive pattern of inheritance, which suggests that an abnormal gene or group of genes is responsible.

To complete this review of genetic factors in congenital heart disease, two further examples from this group are included, the first a family with the Holt-Oram syndrome and the second a family with Hunter's syndrome the sex-linked recessive form of gargoylism.

In 1960 Holt and Oram reported a family in which skeletal deformities of the upper limbs, atrial septal defect, and bizarre arrhythmias occurred in 4 generations. These abnormalities were inherited as an autosomal 


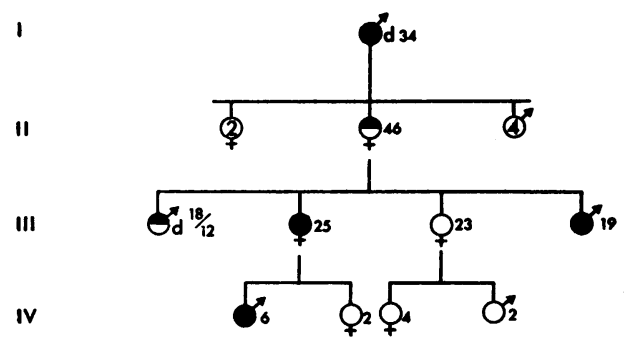

$b$

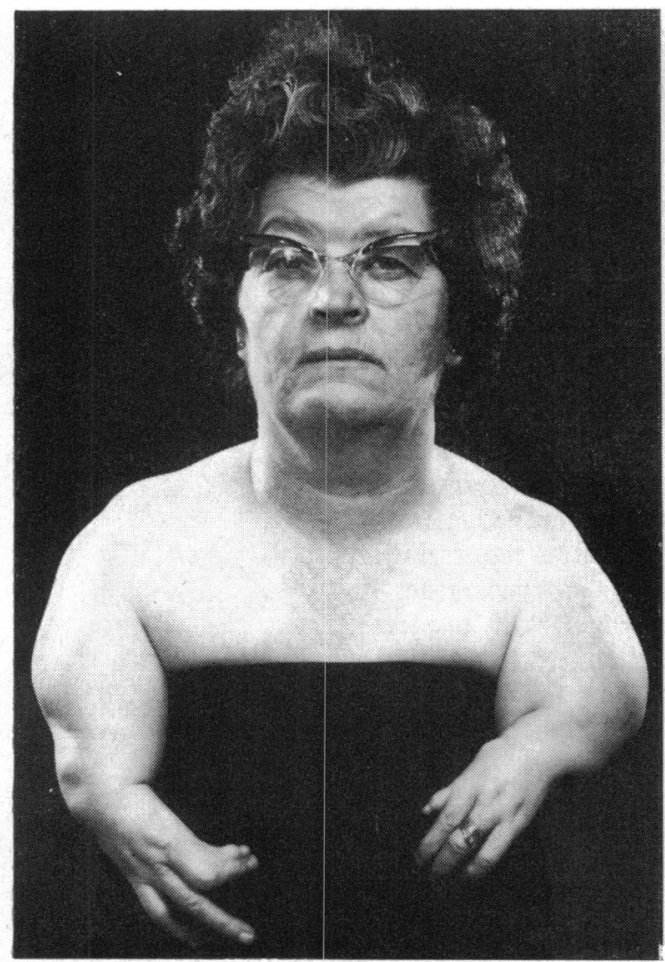

dominant. Similar examples have been reported during the past 8 years (Kuhn, Schaaf, and Wagner, 1963; Pruzanski, I964; Emerit et al., 1965; Holmes, 1965; Lewis et al., 1965; Massumi and Nutter, 1966; Gall et al., 1966; Starke, Schimke, and Dunn, 1967). In the family personally studied there were 6 affected members in 4 generations (Fig. 5).
FIG. 5 (5a) Pedigree of the Holt-Oram family with 6 affected members in 4 generations. In generation $I$, a man who died at the age of 34 years was known to have a cardiac murmur. In generation II there was a woman (Fig. 5b) with absent humeri and vestigial upper limbs, whose heart appeared normal. In generation III, 3 of 4 sibs were affected. The first, a boy, who died at I 8 months, had abnormal limbs, and no information was available about his heart. The second (5c), a woman of 25 years, had a large secundum atrial septal defect measuring $6 \times 6 \mathrm{~cm}$. at operation; she also had a digitalized left thumb, with a long metacarpal and an extra phalanx, in addition to an abnormal head to the right radius. The third, a man of I9 years, had Eisenmenger's syndrome and abnormal thumbs fused with the first fingers. In generation IV, there was a 6-year-old boy with a small ventricular septal defect whose little finger was slightly abnormal.

$c$
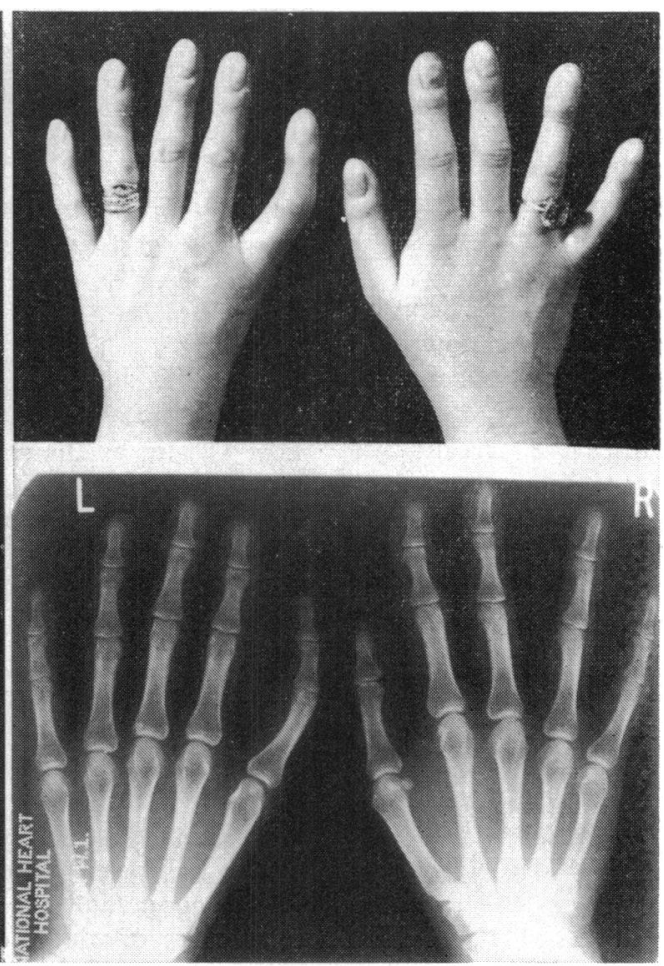

The association between upper limb deformities and congenital heart disease is not uncommon, but it is rare to find congenital heart disease with lower limb abnormalities. A possible explanation is that the heart and upper limbs develop simultaneously and a teratogen affecting the foetus at that time could cause developmental abnormalities in both. The lower limbs develop later and may there- 
fore escape the earlier genetic influences (Woollam, 1962).

Other points of genetic and cardiological interest arising from the Holt-Oram syndrome are whether the rare family with an isolated secundum atrial septal defect inherited as an autosomal dominant, and the familial cases of secundum atrial septal defect in which there are conduction defects and unusual electrocardiograms, could be formes frustes of the syndrome. We have studied one such family, but no defect of the upper limbs was found on either clinical or radiological examination.

The second example is gargoylism, a syndrome that 50 years ago was no more than a clinical curiosity and is now a well-understood clinical, biochemical, and genetic entity. In 1917, Hunter described 2 brothers affected with dwarfism, hepato-splenomegaly, skeletal deformities, coarse facial features, and mental retardation. In 1920 Hurler reported several unrelated children with similar clinical features who also had corneal opacities, and subsequently Ellis, Sheldon, and Capon (1936) called them 'gargoyles' to describe their grotesque appearance. The modern concept of this disease dates from Brante's (1952) observation that the stored material in Hurler's and Hunter's syndromes was acid mucopolysaccharide.

During the past decade related conditions have been described and are now collectively known as the mucopolysaccharidoses (McKusick, I964). In many of these, cardiovascular abnormalities are present but may not become apparent for some years after birth. This point was well shown in a family which included 4 cases of Hunter's syndrome (Fig. 6). The two affected men who died from heart failure, aged 27 and 20 years, have been reported earlier (Emanuel, 1954). Their nephews were thought to be normal at birth but the stigmata of gargoylism

FIG. 6 The pedigree of a family with Hunter's syndrome, the sex-linked recessive form of gargoylism (see text).

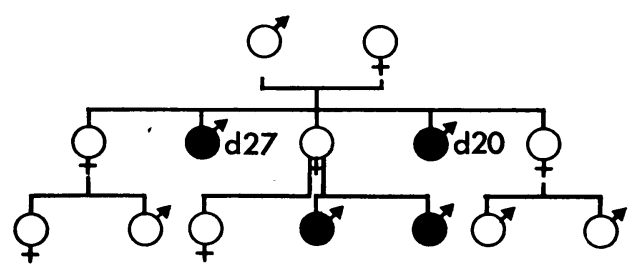

Gargoyle

Normal

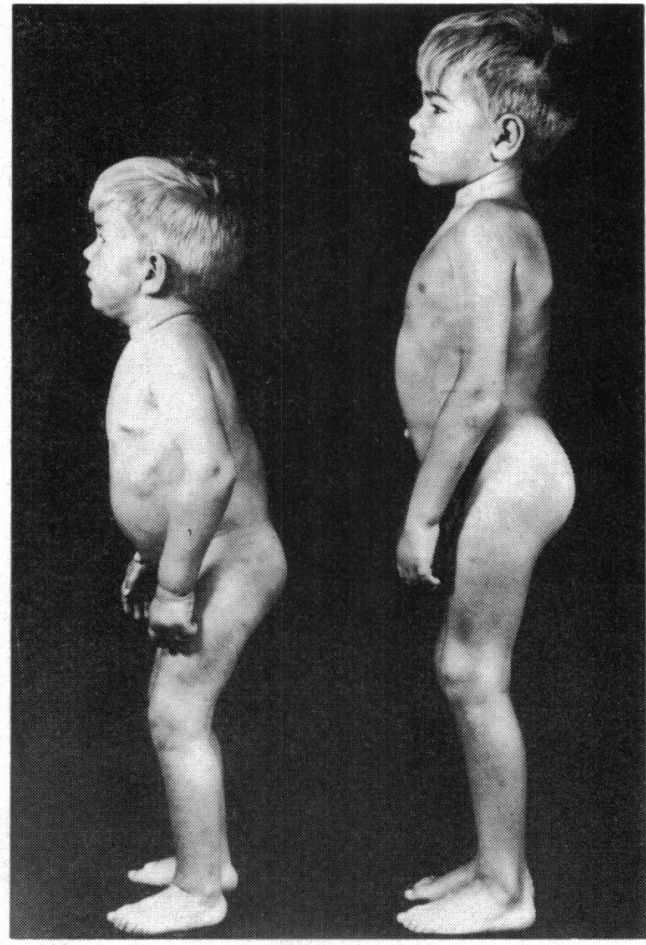

FIG. 7 The 2 male gargoyles, aged $2 \frac{1}{2}$ and 5 years, from the second affected generation (see Fig. 6).

became apparent before the age of 2 years (Fig. 7), and by the age of $2 \frac{1}{2}$ years one child had developed an aortic ejection murmur, and by the age of 5 the other had a mitral pansystolic murmur, and mitral regurgitation was confirmed by cardiac catheterization. In all probability these lesions will progress, and the children, like their uncles, will develop severe valve regurgitation, pulmonary hypertension, and will ultimately die from cardiac failure.

In this review, the presence of genetic factors has been shown in all 3 groups into which congenital heart disease has been arbitrarily divided, but the relative importance of these factors compared with environmental influences has still to be determined, particularly in isolated congenital heart disease. Progress has been made since Lancisi (I745) wrote:- No one will deny that diseases of the heart can be handed down from parents to children. Certainly a defect of this sort is sometimes deeply branded and handed down from the very moment of conception' but much research 
is still needed, not only into the aetiology of congenital heart disease but also into the genetics of coronary heart disease, hypertension, and the arrhythmias.

I am grateful to many physicians in this country and abroad for referring cases of genetic interest. I am also indebted to Dr. Jane Somerville and Mrs. Kay O'Brien for their help in preparing the script.

\section{References}

Anders, J. M., Moores, E. C., and Emanuel, R. (1965). Chromosome studies in 156 patients with congenital heart disease. British Heart fournal, 27, 756.

Anderson, R. C. (1954). Causative factors underlying congenital heart malformations. Patent ductus arteriosus. Pedriatrics 14, 143.

Bell, J. (1940). A determination of the consanguinity rate in the general hospital population of England and Wales. Annals of Eugenics, 10, 370.

Berg, J. M., Crome, L., and France, N. E. (1960). Congenital cardiac malformations in mongolism. British Heart fournal, 22, 331.

Brante, G. (1952). Gargolyism - a mucopolysaccharidosis. Scandinavian fournal of Clinical and Laboratory Investigation, 4, 43.

Burman, D. (196I). Familial patent ductus arteriosus. British Heart fournal, 23, 603.

Campbell, M. (196I). Twins and congenital heart disease. Acta Geneticae Medicae et Gemellologiae, Io, 443.

- (1962). Factors in the aetiology of pulmonary stenosis. British Heart fournal, 24, 625 .

- (1965). Causes of malformations of the heart. British Medical fournal, 2, 895.

- , and Goodwin, J. (1965). Some factors in the etiology of ventricular septal defect. Progress in Cardiovascular Disease, 7, 417.

- , and Polani, P. E. (I96ra). The aetiology of coarctation of the aorta. Lancet, I, 463.

- , and - $(196 \mathrm{rb})$. Factors in the aetiology of atrial septal defect. British Heart fournal, 23, 477.

Carlgren, L.-E. (1959). The incidence of congenital heart disease in children born in Gothenburg 194I-1950. British Heart fournal, 21, 40.

Christensen, F. K., and Nelson, R. M. (1963). Similar congenital heart disease in siblings. fournal of Thoracic and Cardiovascular Surgery, 45, 592.

Court Brown, W. M., Jacobs, P. A., and Brunton, $M$. (1965). Chromosomal studies on randomly chosen men and women. Lancet, 2, 56r.

Detweiler, D. K. (1964). Genetic aspects of cardiovascular diseases in animals. Circulation, 30, II4.

Dogramaci, I., and Green, H. (1947). Factors in the etiology of congenital heart anomalies. Fournal of Pediatrics, 30, 295.

Ellis, R. W. B., Sheldon, W., and Capon, N. B. (1936). Gargoylism: (chondro-osteo-dystrophy, corneal opacities, hepato-splenomegaly, and mental deficiency). Quarterly fournal of Medicine, n.s. 5, II9.

Emanuel, R., Nichols, J., Anders, J. M., Moores, E. C., and Somerville, J. (1968). Atrioventricular defects a study of 92 families. British Heart fournal, 30, 645.

Emanuel, R. W. (1954). Gargoylism with cardiovascular involvement in two brothers. British Heart fournal, 16, 417.
Emerit, I., de Grouchy, J., Laval-Jeantet, M., Corone, P., and Vernant, P. (1965). Malformations complexes des membres supérieurs associées à une cardiopathie congénitale. A propos de six observations. Acta Geneticae Medicae et Gemellologiae, $14,132$.

Emsbö, P. (1955). Subaortal stenose. Komparative studier over medfodt subvalvulaer aortastenose (venstresidig konusstenose) hos svin og menneske. Dansk Videnskabbs Forlag A/S, Copenhagen.

Falconer, D. S. (1965). The inheritance of liability to certain diseases, estimated from the incidence among relatives. Annals of Human Genetics, 29, 5 I.

Fox, M. Hopkins (1967). Genetic transmission of congenital membranous ventricular septal defects in selectively inbred substrains of rats. Circulation Research, 20, 422.

Frank, S., and Braunwald, E. (1968). Idiopathic hypertrophic subaortic stenosis. Clinical analysis of 126 patients, with emphasis on the natural history. Circulation, 37, 759.

Fuhrmann, W. (1962). Genetische und peristatische Ursachen angeborener Angiokardiopathien. Ergebnisse der inneren Medizin und Kinderheilkunde, n.s. $18,47$.

(1968a). Congenital heart disease in sibships ascertained by two affected siblings. Humangenetik, 6, $\mathrm{x}$.

- (1968b). A family study in transposition of the great vessels and in tricuspid atresia. Humangenetik, 6, 148.

Gall, J. C., Jr., Stern, A. M., Cohen, M. M., Adams, M. S., and Davidson, R. T. (1966). Holt-Oram syndrome: clinical and genetic study of a large family. American fournal of Human Genetics, 18, I87.

Gänsslen, M., Lambrecht, K., and Werner, M. (1940). Die Kongenitalen Missbildung des Herzens. In Handbuch der Erbbiologie des Menschen, Vol. 4, p. 198. Ed. by G. Just. J. Springer, Berlin.

German, J., Ehlers, K. H., and Engle, M. A. (1966). Familial congenital heart disease. II. Chromosomal studies. Circulation, 34, 517.

Goodwin, J. F., Hollman, A., Cleland, W. P., and Teare, D. (1960). Obstructive cardiomyopathy simulating aortic stenosis. British Heart fournal, 22, 403.

Harvald, B., and Hauge, M. (1965). Hereditary factors elucidated by twin studies. U.S. Dept. of Health, Education $\mathcal{E}$ Welfare, Public Health Service Publication, No. 1163, p. 61.

Hollman, A., Goodwin, J. F., Teare, D., and Renwick, J. W. (1960). A family with obstructive cardiomyopathy (asymmetrical hypertrophy). British Heart fournal, 22, 449.

Holman, E., Gerbode, F., and Purdy, A. (1953). The patent ductus: a review of 75 cases with surgical treatment including an aneurysm of the ductus and one of the pulmonary artery. fournal of Thoracic Surgery, 25, 1 I I.

Holmes, L. B. (1965). Congenital heart disease and upper-extremity deformities. New England fournal of Medicine, 272, 437.

Holt, M., and Oram, S. (1960). Familial heart disease with skeletal malformations. British Heart fournal, 22, 236.

Howitt, G. (196r). Atrial septal defect in three generations. British Heart fournal, 23, 494.

Hunter, C. (1917). A rare disease in two brothers. Proceedings of the Royal Society of Medicine, ro, Section for the Study of Disease in Children, $p$. I04. 
Hurler, G. (1920). Úber einen Typ multipler Abartungen, vorwiegend am Skelettsystem. Zeitschrift fürKinderheilkunde, 24, 220.

Kuhn, E., Schaaf, J., and Wagner, A. (1963). Primary pulmonary hypertension, congenital heart disease and skeletal anomalies in three generations. fapanese Heart fournal, 4, 205.

Lamy, M., de Grouchy, J., and Schweisguth, $O$. (1957). Genetic and non-genetic factors in the etiology of congenital heart disease: a study of I 88 cases. American fournal of Human Genetics, 9, 17.

Lancet (1965). Leading article. Making sense of Turner's syndrome. Human Genetics, 2, 529.

Lancisi, G. M. (1745). On the hereditary disposition to aneurysms of the heart. In De Aneurysmatis. Aneurysms: The Latin Text of Rome, 1745, p. 213. Revised, with translation and notes by W. C. Wright. Macmillan, New York (1952).

Lewis, K. B., Bruce, R. A., Baum, D., and Motulsky, A. G. (1965). The upper limb-cardiovascular syndrome. An autosomal dominant genetic effect on embryogenesis. Fournal of the American Medical Association, 193, 1080.

Logan, W. F. W. E., Jones, E. W., Walker, E., Coulshed, N., and Epstein, E. J. (1965). Familial supravalvar aortic stenosis. British Heart fournal, $27,547$.

McAleese, J. J. (1952). A survey of congenital heart disease in a children's hospital with special reference to surgical treatment. American fournal of Surgery, 83, 755.

McKeown, T., MacMahon, B., and Parsons, C. G. (1953). The familial incidence of congenital malformation of the heart. British Heart fournal, 15, 273.

—, and Record, R. G. (1960). Malformations in a population observed for five years after birth. In CIBA Foundation Symposium on Congenital Malformations, p. 2. Ed. by G. E. W. Wolstenholme and C. M. O'Connor. J. and A. Churchill, London.

McKusick, V. A. (I964). A genetical view of cardiovascular disease. Circulation, 30, 326.

Massumi, R. A., and Nutter, D. O. (1966). The syndrome of familial defects of heart and upper extremities (Holt-Oram syndrome). Circulation, 34,65 .

Merritt, A. D., Palmer, C. G., Lurie, P. R., and Petry, E. L. (1963). Supravalvar aortic stenosis: genetic and clinical studies. Fournal of Laboratory and Clinical Medicine, 62, 995.

Migeon, B. R., and Whitehouse, D. (1967). Familial occurrence of the somatic phenotype of Turner's syndrome. Fohns Hopkins Medical fournal, 120, 78.

Moores, E. C., Anders, J. M., and Emanuel, R. (I966). Inheritance of marker chromosomes from a cytogenic survey of congenital heart disease. Annals of Human Genetics, 30, 77.

Mustacchi, P., Sherins, R. S., and Miller, M. J. (1963). Congenital malformations of the heart and the great vessels. Fournal of the American Medical Association, 183, 241.

$\mathrm{Nie}, \mathrm{C}$. J. van (1963). The ostium atrioventriculare commune persistens in animals. (A report of two cases, occurring in a calf and in a pig respectively.) Tijdschrift voor Diergeneeskunde, 88, 205.

Nora, J. J., Campbell Gilliland, J., Sommerville, R. J., and McNamara, D. G. (I967a). Congenital heart disease in twins. New England fournal of Medicine, 277, 568.

-, McNamara, D. G., and Fraser, F. Clarke (1967b). Hereditary factors in atrial septal defect. Circulation, 35, 448.
Patterson, D. F. (1965). Congenital heart disease in the dog. Annals of the New York Academy of Sciences, 127, 541.

- (1968). Epidemiologic and genetic studies of congenital heart disease in the dog. Circulation Research, 23, 171.

- , and Detweiler, D. K. (1967). Hereditary transmission of patent ductus arteriosus in the dog. American Heart fournal, 74, 289.

Pitt, D. B. (1962). A family study of Fallot's tetrad. Australasian Annals of Medicine, 11, 179.

Polani, P. E. (1962). Sex chromosome anomalies in man. In Chromosomes in Medicine (Little Club Clinics in Development Medicine, No. 5), p. 73. Ed. by J. L. Hamerton. National Spastics Society and Heinemann Medical Books, London.

- (1968). Chromosomal abnormalities and congenital heart disease. Guy's Hospital Reports, 117, 323.

, and Campbell, M. (1955). An aetiological study of congenital heart disease. Annals of Human Genetics, 19, 209.

- , and - (1960). Factors in the causation of persistent ductus arteriosus. Annals of Human Genetics, 24, 343.

- Hunter, W. F., and Lennox, B. (1954). Chromosomal sex in Turner's syndrome with coarctation of the aorta. Lancet, 2, 120.

Pruzanski, W. (1964). Familial congenital malformations of the heart and upper limbs. A syndrome of Holt-Oram. Cardiologia, 45, 21.

Richards, M. R., Merritt, K. K., Samuels, M. H., and Langmann, A. G. (I955). Congenital malformations of the cardiovascular system in a series of 6,053 infants. Pediatrics, 15, 12.

Roberts, J. A. F. (1955). Cousin marriage. Medical fournal of the South-West, 70, 142.

Ross, L. J. (1959). Congenital cardiovascular anomalies in twins. Circulation, 20, 327.

Rowe, R. D. (1962). Cardiac malformation in mongolism. American Heart fournal, 64, 567.

- , and Uchida, I. A. (196I). Cardiac malformation in mongolism. American fournal of Medicine, 31, 726.

Sasaki, M. S., Makino, S., and Kajii, T. (1963). Chromosomal aberrations in congenital cardiovascular disorders of man. Proceedings of the fapan Academy, 39, 394.

Siller, W. G. (1958). Ventricular septal defects in the fowl. Fournal of Pathology and Bacteriology, 76, 431 .

Smithells, R. W. (1968). Incidence of congenital abnormalities in Liverpool, 1960-64. British Fournal of Preventive and Social Medicine, 22, 36.

Starke, H., Schimke, R. N., and Dunn, M. (1967). Upper-limb cardiovascular syndrome. A family study. American fournal of Cardiology, 19, 588.

Teare, D. (1958). Asymmetrical hypertrophy of the heart in young adults. British Heart fournal, 20, I.

Uchida, I. A., and Rowe, R. D. (1957). Discordant heart anomalies in twins. American fournal of Human Genetics, 9, 133.

Vernant, P., Corone, P., De Grouchy, J., De Gennes, J.-L., and Emerit, I. (1966). Le coeur dans le syndrome de Turner-Ullich. Étude de 26 cas personels et revue des observations comportant une étude chromosomique. Archives des Maladies du Coeur et des Vaisseaux, 59, 850.

Warkany, J., Passarge, E., and Smith, L. B. (1966). Congenital malformations in autosomal trisomy syndromes. American fournal of Diseases of Children, $112,502$.

Watson, H. (I968). Paediatric Cardiology. Lloyd-Luke (Medical Books), London. 
Weber, W. W., Mamunes, P., Day, R., and Miller, P. (1964). Trisomy 17-18 (E): studies in longterm survival with report of two autopsied cases. Pediatrics, 34, 533.

Wilkins, J. L. (1969). Risks to offspring of patients with patent ductus arteriosus. Fournal of Medical Genetics, 6, I.

WHO Meeting of Investigators on Methodology of Twin Studies (1966). The use of twins in epidemiological studies. Acta Geneticae Medicae et Gemellologiae, 15, 109.

Woollam, D. H. M. (1962). Thalidomide disaster considered as an experiment in mammalian teratology. British Medical fournal, 2, 236.

Zoethout, H. E., Bonham Carter, R. E., and Carter, C. O. (1964). A family study of aortic stenosis. fournal of Medical Genetics, $\mathbf{1}, 2$.

Zuckerman, H. S., Zuckerman, G. H., Mammen, R. E., and Wassermil, M. (1962). Atrial septal defect. Familial occurrence in four generations of one family. American fournal of Cardiology, 9, 515. 